\title{
Modeling net energy requirements of 2 to 3-week-old Cherry Valley ducks
}

\author{
Ting Yang ${ }^{1, a}$, Lexiao Yu ${ }^{1, a}$, Min Wen ${ }^{1,2}$, Hua Zhao ${ }^{1}$, Xiaoling Chen ${ }^{1}$, Guangmang Liu', \\ Gang Tian', Jingyi Cai ${ }^{1}$, and Gang Jia,*
}

\author{
* Corresponding Author: Gang Jia \\ Tel: +86-13608260976, Fax: +86-028-86290920, \\ E-mail: jiagang700510@163.com \\ 1 Institute of Animal Nutrition, Sichuan Agricultural \\ University, Chengdu, 611130, China \\ ${ }^{2}$ College of Animal Science and Technology, Tibet \\ Vocational Technical College, Lasa, 850000, China \\ a These authors contributed equally to this work. \\ ORCID \\ Ting Yang \\ https://orcid.org/0000-0001-6241-1882 \\ Lexiao Yu \\ https://orcid.org/0000-0002-7115-8572 \\ Min Wen \\ https://orcid.org/0000-0003-0915-2433 \\ Hua Zhao \\ https://orcid.org/0000-0002-0334-4189 \\ Xiaoling Chen \\ https://orcid.org/0000-0002-5792-1703 \\ Guangmang Liu \\ https://orcid.org/0000-0003-2385-7528 \\ Gang Tian \\ https://orcid.org/0000-0001-7301-5949 \\ Jingyi Cai \\ https://orcid.org/0000-0002-3194-0105 \\ Gang Jia
}

https://orcid.org/0000-0003-1102-0683

Submitted Jul 11, 2019; Revised Sept 17, 2019; Accepted Oct 30, 2019
Objective: A total of three hundred unsexed ducks were utilized to estimate net energy requirements of maintenance $\left(\mathrm{NE}_{\mathrm{m}}\right)$ and weight gain $\left(\mathrm{NE}_{\mathrm{g}}\right)$ for 2 to 3 -week-old Cherry Valley ducks and to establish a model equation to predict NE requirements using the factorial method.

Methods: To determine the apparent metabolizable energy (AME) of the diet, fifty 7-day-old ducks at approximately equal body weights (BWs) were randomly assigned into five groups that were fed at different levels (ad libitum, $85 \%, 75 \%, 65 \%$, and $55 \%$ of ad libitum intake), and the endogenous acid-insoluble ash as indigestible marker. The two hundred and fifty 7-day-old ducks were used for a comparative slaughter experiment. At the beginning of the experiment, ten ducks were sacrificed to determine the initial body composition and energy content. The remaining ducks were randomly assigned into five groups (same as metabolic experiment). Ducks of the ad libitum group were slaughtered at 14 and 21-dayold. At the end of the experiment, two ducks were selected from each replicate and slaughtered to determine the body composition and energy content.

Results: The results of the metabolizable experiment showed AME values of 13.43 to 13.77 $\mathrm{MJ} / \mathrm{kg}$ for ducks at different feed intakes. The results of the comparative slaughter experiment showed the $\mathrm{NE}_{\mathrm{m}}$ value for 2 to 3-week-old Cherry Valley ducks was $549.54 \mathrm{~kJ} / \mathrm{kg}$ of BW $\mathrm{BW}^{0.75} / \mathrm{d}$, and the $\mathrm{NE}_{\mathrm{g}}$ value was $10.41 \mathrm{~kJ} / \mathrm{g}$. The deposition efficiency values of fat $\left(\mathrm{K}_{\mathrm{f}}\right)$ and crude protein $\left(\mathrm{K}_{\mathrm{p}}\right)$ were 0.96 and 0.60 , respectively, and the values of efficiency of energy utilization $\left(\mathrm{K}_{\mathrm{g}}\right)$ and maintenance efficiency $\left(\mathrm{K}_{\mathrm{m}}\right)$ were 0.75 and 0.88 , respectively.

Conclusion: The equation for the prediction of NE requirements for 2 to 3-week-old Cherry Valley ducks was the following: $\mathrm{NE}=549.54 \mathrm{BW}^{0.75}+10.41 \Delta \mathrm{W}$, where $\Delta \mathrm{W}$ is the weight gain (g).

Keywords: Duck; Net Energy Requirement; Factorial Method; Comparative Slaughter Method; Prediction Equation

\section{INTRODUCTION}

Accurate estimates of the nutritional requirements of animals and the nutritive value of feed ingredients are essential when formulating feed for different species of animals. Energy systems based on digestible energy (DE) value or metabolizable energy (ME) value are widely used in the poultry and pig industries. For broiler chickens, the relative efficiency of energy utilization for carbohydrate, fat and protein was determined to be $100 \%, 113 \%$, and $78 \%$, respectively [1]. The ME system undervalued the utilizable energy of fats and overestimated that of proteins in comparison with that of carbohydrates because the heat increment (HI) was not accounted for as energy loss [2]. The net energy (NE) system can accurately assess the energy requirements of animals and reflects the true energy value of feedstuffs that are 
used to feed animals, such as unconventional feedstuff $[3,4]$. As the energy requirements of humans continue to increase, and therefore, the adoption of the NE system to fully use unconventional feedstuff to alleviate this energy shortage is critical, such as food by-products. In the pig industry, a savings of 4.00 to $4.50 € / t$ of feed cost is possible, and the excretion of nitrogen is also reduced when the ME system is replaced by the NE system, without negative effects on production performance $[5,6]$. The nitrogen retained in diets with co-products is not affected when the imbalances in the amino acid concentrations or the post-absorptive energy metabolism of diets is taken into account [7]. In recent years, the ME or the DE systems have been substituted gradually by the NE system in pig husbandry of North America and Europe [8].

The NE requirements of animals can be determined using the factorial method that divides the $\mathrm{NE}$ requirements into maintenance $\left(\mathrm{NE}_{\mathrm{m}}\right)$ and production $\left(\mathrm{NE}_{\mathrm{p}}\right)$ requirements [9]. In general, maintenance requirements are independent of animal production level and nutritional composition of feed and are only related to the state of the animal [10]. The HI depends on environmental temperature, the amount of feed consumed, and also varies with the feeding time and duration of fasting, the most important factor of variation of $\mathrm{HI}$ is the diet composition [10-12]. The heat production (HP) of an animal can be determined using indirect calorimetry, and the fasting heat production (FHP) of an animal is commonly used to estimate the $\mathrm{NE}_{\mathrm{m}}$ [13]. In previous studies, indirect calorimetry was used to determine the values of ingredients and NE requirements of ruminants, pigs, broilers, and breeder pullets $[14,15]$. However, Milgen and Noblet [16] raised objections to this method because the locomotor activity of animals is restricted, then, the collected data may not reflect the true HP of animals reared under normal conditions. The previous level of intake also affect the FHP because the fasting status influences the animal physiological state, which is associated with $\mathrm{HP}$ of animals $[10,15,17]$. Therefore, another method for the determination of the $\mathrm{NE}_{\mathrm{m}}$ of animals is the regression method, as proposed by Lofgreen and Garrett [18]. The regression method mostly avoids the metabolic change caused by starvation, and the NE value is more accurate than that obtained with the calorimetric method. For poultry, the requirements of NE for growth, based on compounds that are deposited in the body, can be determined via the comparative slaughter method. Thus, we determined the NE requirements of ducks by adopting the regression and comparative slaughter methods.

The NE system has been widely adopted in the pig industry in some countries with developed animal husbandry, but for poultry, the adoption of the NE system is in the initial stage because information remains scarce and data on poultry $\mathrm{NE}$ implementation continue to be accumulated. Therefore, the objective of this study was to establish an equation to predict the NE requirements for 2 to 3-week-old Cherry Valley ducks by determining the $\mathrm{NE}$ requirements of maintenance $\left(\mathrm{NE}_{\mathrm{m}}\right)$ and weight gain $\left(\mathrm{NE}_{\mathrm{g}}\right)$ using the regression and comparative slaughter methods, respectively.

\section{MATERIALS AND METHODS}

\section{Animal care}

The experimental procedures for animal trials were conducted in accordance with the Chinese guidelines for animal welfare and approved by the Animal Health and Care Committee (IACUC) of Sichuan Agricultural University (SAU14-158).

\section{Animal, experimental design and diets}

A total of three hundred unsexed, 1-day-old Cherry Valley ducks (male and female) were reared in cage pens $(1 \mathrm{~m} \times 1 \mathrm{~m})$ at the farm of the Animal Nutrition Institute of Sichuan Agricultural University. The ducks (initial weight $55.37 \pm 0.26 \mathrm{~g}$ ) were acclimated to the environment for 7 days. Ducks were fed with pellet form, and free access to feed and water throughout the experiment. The diet was based on corn-soybean meal and formulated to meet or slightly exceed NRC (1994) nutrient recommendations (Table 1). The temperature maintained at $32^{\circ} \mathrm{C}$ during the first week, and gradually decrease to $24^{\circ} \mathrm{C}$ at the end of the third week and then kept constant thereafter. All ducks were housed in an environmentally controlled facility, with continuous $24 \mathrm{~h}$ lighting.

In order to determine the apparent metabolizable energy (AME) of the experimental diet at different feeding level. A total of fifty 7-day-old ducks at approximately equal body weights (BWs, regardless of sex) were randomly assigned into five treatments with five replicates, each replicate containing two birds. The birds were provided diet at five levels of feed (ad libitum and 85\%, 75\%,65\%, and 55\% ad libitum intake). The intake of feed restriction was confirmed by intake of ducks allowed ad libitum intake of previous day, and the experiment lasted eight days. The endogenous acid-insoluble ash (AIA) as an indigestible marker to measure the AME of experimental diets during this period.

A total of two hundred and fifty 7-day-old ducks were used for the comparative slaughter experiment. At the beginning of the experiment, ten ducks at approximately equal BWs were sacrificed to determine the initial body composition and energy content. The remaining ducks were randomly assigned into five groups (same as the metabolic experiment); the ad libitum group was replicated ten times, and the restriction groups were replicated five times, each replicate with eight ducks. At 14 days of age, ten ducks (BWs) were selected from five replicates of ad libitum group and sacrificed to determine the body composition. At 21 days of age, two ducks (BWs) were selected from each of the replicates were sacrificed to 
Table 1. Ingredient and nutrient levels of diet for ducks (on an air-dry basis)

\begin{tabular}{lc}
\hline Items & \\
\hline Ingredient (\%) & 62.9 \\
Corn & 26.5 \\
Soybean meal & 5 \\
Cottonseed meal & 0.85 \\
Soybean oil & 0.86 \\
Unite bran & 1.16 \\
Limestone & 1.46 \\
Calcium hydrophosphate & 0.3 \\
Sodium chloride & 0.2 \\
Choline chloride & 0.53 \\
Premix & 0.03 \\
L-lysine & 0.17 \\
DL-methionine & 0.04 \\
Tryptophan & 100 \\
Total & \\
Calculated nutrients & 12.03 \\
Metabolizable energy (MJ/kg) & 20.01 \\
Crude protien & 0.90 \\
Calcium & 0.40 \\
Available phosphorus & 0.90 \\
Lysine & 0.74 \\
Methionine+systeine & 0.59 \\
Threonine & 0.24 \\
Tryptophan & \\
\hline Provided & \\
\hline
\end{tabular}

1) Provided per kilogram of diet: vitamin $A, 4,000 \mathrm{IU}$; vitamin $D_{3}, 1,200 \mathrm{IU}$; vitamin $E_{1}, 18 \mathrm{mg}$; vitamin $K_{3}, 1.5 \mathrm{mg}$; vitamin $B_{1}, 0.9 \mathrm{mg}$; vitamin $B_{2}, 2.6 \mathrm{mg}$; vitamin $B_{6,} 2$ $\mathrm{mg}$; vitamin $B_{12}, 0.01 \mathrm{mg}$; pantothenic acid, $4.5 \mathrm{mg}$; nicotinic acid, $24 \mathrm{mg}$; biotin, $0.045 \mathrm{mg}$; folic acid, $0.6 \mathrm{mg}$; Cu (as copper sulfate pentahydrate), $8.0 \mathrm{mg}$; Zn (as zinc sulfate monohydrate), 90 mg; Fe (as ferrous sulfate monohydrate), 80 mg; Mn (as manganese sulfate monohydrate), $70 \mathrm{mg}$; Se (as sodium selenite), $0.3 \mathrm{mg}$; I (as potassium iodide), $0.4 \mathrm{mg}$.

determine the final body composition.

\section{Sample collections and chemical analysis}

For the metabolic experiment, excreta were collected three times per day for three days. The feathers, skin debris and spilled feed were carefully removed, the excreta were weighed, $10 \mathrm{~mL}$ of $10 \%$ hydrochloric acid and drops of toluene were added, and the excreta was stored at $-20^{\circ} \mathrm{C}$. At the end of collection, the collected excreta was pooled by replicating and dried in a forced-ventilation greenhouse for $72 \mathrm{~h}$ at $65^{\circ} \mathrm{C}$. After milling of excreta, the samples were sent for analyses of dry matter, energy and AIA.

For the comparative slaughter experiment, ducks were fasted overnight by withdrawal of feed only. After weighing, ducks were euthanized by cervical dislocation, and the carcasses were frozen at $-20^{\circ} \mathrm{C}$ with feathers and viscera. The frozen ducks were chopped into small pieces, and the pieces were passed through the grinder five times to prepare representative samples for analyses. The carcasses samples were weighed, homogenized and dried in a forced-ventilation oven for $96 \mathrm{~h}$ at $55^{\circ} \mathrm{C}$. After $24 \mathrm{~h}$, the carcasses samples were reweighed and ground to determine the body composition.

According to the procedure of AOAC (Association of Official Analytical Chemists) [19], the diet, excreta and carcass sample were dried at $105^{\circ} \mathrm{C}$ for $8 \mathrm{~h}$ to determine the dry matter. Total nitrogen of carcass sample was assayed using the Kjeldahl method, and ether extract of carcass sample was determined by extraction in anhydrous ether in a Soxhlet apparatus for $12 \mathrm{~h}$. The gross energy of diet, excreta and carcass sample were measured in an automatic oxygen bomb calorimeter (PARR 6400; PARR Instruments CO., Moline, IL, USA). The AIA of diet and excreta were measured according to ISO 5985-2002.

\section{Data calculation}

The BW gain was determined by calculating the difference in weight between the beginning and the end of the experiment. The amounts of feed and orts were weighed daily to calculate the feed intake. The data obtained from the metabolic experiment were used to calculate the AME of the diet using the endogenous indicator method.

The retained energy (RE) of body was determined by the difference between the initial and the final carcasses energy content (BE). The HP was defined as the difference between ME intake (MEI) and RE [20]. The $\mathrm{NE}_{\mathrm{m}}$ was calculated form the antilog of the $y$-axis intercepts of the linear regression between the $\log _{10} \mathrm{HP}$ and MEI [18]. The ME requirements for maintenance $\left(\mathrm{ME}_{\mathrm{m}}\right)$ were calculated from the regression equation between the RE and MEI, with the intercept on the $\mathrm{x}$-axis representing the $\mathrm{ME}_{\mathrm{m}}$ and the slope of regression between RE and MEI above maintenance representing the efficiency of ME utilization for retained energy $\left(\mathrm{K}_{\mathrm{g}}\right)$ [21]. The efficiency of ME utilization for maintenance $\left(K_{m}\right)$ was calculated as $\mathrm{NE}_{\mathrm{m}}$ divided by $\mathrm{ME}_{\mathrm{m}}$.

The $\mathrm{NE}_{\mathrm{g}}$ was obtained from the linear regression equation between $\mathrm{BE}$ and $\mathrm{BW}$, and the slope of the equation was the $\mathrm{NEg}$. The ME requirements of weight gain $\left(\mathrm{ME}_{\mathrm{g}}\right)$ were calculated as $\mathrm{NE}_{\mathrm{g}}$ divided by $\mathrm{Kg}$. The total efficiency of energy deposition as protein $\left(\mathrm{K}_{\mathrm{p}}\right)$ and fat $\left(\mathrm{K}_{\mathrm{f}}\right)$ was determined by multiple linear regression of MEI and RE as protein and fat according to the model proposed by Boekholt et al [22]. The deposition protein was calculated as nitrogen of carcass multiplied by 6.25 . The energy requirement of deposition as fat and protein are $39.22 \mathrm{~kJ} / \mathrm{g}$ and $23.69 \mathrm{~kJ} / \mathrm{g}$, respectively [20]. The $K_{p}$ and $K_{f}$ are the efficiency of energy utilization of deposited protein and fat in this formula, respectively.

\section{Statistical analysis}

Data are shown as the means \pm standard error, and were analyzed using the SPSS 19.0 (SPSS Inc., Chicago, IL, USA). Normal distribution and homogeneity of variance using were checked the Shapiro-Wilk and Levene's tests, respectively. 
When data exhibited normally distributed and homogeneity, they were analysed using one-way analysis of variance and followed by the Duncan's comparison. In addition, the linear regression equations about $\log _{10} \mathrm{HP}$, MEI, and RE, MEI were established by the general linear model procedure, and the $\mathrm{R}^{2}$ was used to compare these regressions. Statistical significance is defined as $\mathrm{p}<0.05$

\section{RESULTS}

The performance and body composition of ducks

The results for duck performance at the different levels of intake are summarized in Table 2. The ADFI and ADG of ducks decreased and the feed conversion ratio (FCR) increased with decreasing feed intake, except between the ad libitum group and the $15 \%$ restriction group; therefore, the feed conversion increased when ducks were in a state of hunger. Table 3 shows the results of energy balances and body retained parameters. The BE and fat deposition declined as the supply of feed decreased. By contrast, protein deposition and carcasses moisture increased with the decrease in the level of intake. No significant difference was observed between the $15 \%$ and $25 \%$ restriction groups for carcasses moisture, and protein deposition was also not different between similar restriction groups (i.e., ad libitum and 15\% restriction group and 35\% and 45\% restriction groups).

\section{Energy requirements for maintenance of ducks}

In the experiment to determine the AME values, the apparent metabolizable rate of energy (AM) for the ad libitum group of ducks was $79.44 \%$, which increased slightly to $81.39 \%$ (55\% ad libitum group) with the decrease in the level of intake. The
AME values of the diet for ducks increased from $13.43 \mathrm{MJ} / \mathrm{kg}$ (ad libitum group) to $13.77 \mathrm{MJ} / \mathrm{kg}$ (55\% ad libitum group) (Table 4); however, no significant difference was detected between the two lowest levels of feeding (65\% and 55\% ad libitum groups).

The MEI of ducks at different levels of intake are shown in Table 4. The MEI of the ad libitum group was $1,934.25 \mathrm{~kJ} / \mathrm{kg}$ of $\mathrm{BW}^{0.75} / \mathrm{d}$, which decreased significantly with the decrease in level of intake as design. The RE and HP also decreased significantly with decreasing feed intake, but the decline of HP was less than that of RE. As shown in Table 5, according to the linear regression equation for RE as a function of MEI, the obtained value of $\mathrm{ME}_{\mathrm{m}}$ was $625.59 \mathrm{~kJ} / \mathrm{kg}$ of $\mathrm{BW}^{0.75} / \mathrm{d}$, and the value of $\mathrm{K}_{\mathrm{g}}$ was 0.75 . Meanwhile, the linear regression equation between MEI and $\log _{10} \mathrm{HP}$ is also presented in Table 5; the value of FHP was $549.54 \mathrm{~kJ} / \mathrm{kg}$ of $\mathrm{BW}^{0.75} / \mathrm{d}$, which was equivalent to the $\mathrm{NE}_{\mathrm{m}}$, and the $\mathrm{K}_{\mathrm{m}}$ value was calculated as 0.88 .

\section{Energy requirements for weight gain of ducks}

From the comparative slaughter experiment, the data of body composition and deposited energy of ducks at different ages are shown in Table 6. The BW and protein and energy content increased with age, whereas the carcasses moisture and fat decreased. The linear regression equation between $\mathrm{BW}$ and BE was established as:

$\mathrm{BE}=-793.02+10.41 \times \mathrm{BW}\left(\mathrm{R}^{2}=0.996\right.$, root mean squared error $[\mathrm{RMSE}]=276.822, \mathrm{n}=15, \mathrm{p}<0.0001)$.

From the equation, the slope of the regression equation indicated the $\mathrm{NE}_{\mathrm{g}}$ was $10.41 \mathrm{~kJ} / \mathrm{g}$. According to the values of

Table 2. The effects of different feed intake on performance of 2 to 3-week-old ducks

\begin{tabular}{|c|c|c|c|c|c|c|c|}
\hline \multirow{2}{*}{ Items } & \multicolumn{5}{|c|}{ Feeding level } & \multirow{2}{*}{ SEM } & \multirow{2}{*}{$p$-value } \\
\hline & Ad libitum & $85 \%$ ad libitum & $75 \%$ ad libitum & $65 \%$ ad libitum & $55 \%$ ad libitum & & \\
\hline ADFI (g) & $113.47^{\mathrm{a}}$ & $95.67^{b}$ & $83.76^{c}$ & $72.61^{d}$ & $61.51^{\mathrm{e}}$ & 0.22 & $<0.001$ \\
\hline ADG (g) & $69.31^{\mathrm{a}}$ & $58.04^{b}$ & $49.91^{c}$ & $42.70^{d}$ & $35.83^{e}$ & 0.22 & $<0.001$ \\
\hline FCR & $1.64^{d}$ & $1.65^{d}$ & $1.68^{c}$ & $1.70^{b}$ & $1.72^{\mathrm{a}}$ & 0.01 & $<0.001$ \\
\hline
\end{tabular}

SEM, standard error of the mean; $A D F I$, average daily feed intake; $A D G$, average daily gain; FCR, feed conversion ratio.

${ }^{a \cdot e}$ Means within a row lacking a common superscript differ $(p<0.05)$.

Table 3. The effects of different feed intake on body composition of 3-week-old ducks

\begin{tabular}{|c|c|c|c|c|c|c|c|}
\hline \multirow{2}{*}{ Items } & \multicolumn{5}{|c|}{ Feeding level } & \multirow{2}{*}{ SEM } & \multirow{2}{*}{$p$-value } \\
\hline & Ad libitum & $85 \%$ ad libitum & $75 \%$ ad libitum & $65 \%$ ad libitum & $55 \%$ ad libitum & & \\
\hline Water (\%) & $63.97^{d}$ & $64.47^{c}$ & $64.59^{c}$ & $65.18^{b}$ & $65.58^{\mathrm{a}}$ & 0.12 & $<0.001$ \\
\hline Energy $(\mathrm{kJ} / \mathrm{g})$ & $9.85^{\mathrm{a}}$ & $9.63^{b}$ & $9.48^{c}$ & $9.21^{d}$ & $9.00^{e}$ & 0.08 & $<0.001$ \\
\hline Protein (\%) & $16.50^{c}$ & $16.75^{c}$ & $17.19^{b}$ & $17.61^{\mathrm{a}}$ & $17.84^{\mathrm{a}}$ & 0.21 & $<0.001$ \\
\hline Fat $(\%)$ & $15.64^{\mathrm{a}}$ & $14.79^{b}$ & $13.73^{c}$ & $12.78^{d}$ & $11.89^{e}$ & 0.16 & $<0.001$ \\
\hline
\end{tabular}

SEM, standard error of the mean.

a.e Means within a row lacking a common superscript differ $(p<0.05)$. 
Table 4. The energy utilization of the diet of 2 to 3 -week-old ducks

\begin{tabular}{|c|c|c|c|c|c|c|c|}
\hline \multirow{2}{*}{ Items } & \multicolumn{5}{|c|}{ Feeding level } & \multirow{2}{*}{ SEM } & \multirow{2}{*}{$\mathrm{p}$-value } \\
\hline & Ad libitum & $85 \%$ ad libitum & $75 \%$ ad libitum & $65 \%$ ad libitum & $55 \%$ ad libitum & & \\
\hline GE in excreta (MJ/kg) & $14.10^{\mathrm{a}}$ & $13.85^{\mathrm{a}}$ & $13.93^{\mathrm{a}}$ & $13.51^{b}$ & $13.39^{b}$ & 0.21 & $<0.001$ \\
\hline AIA in excreta (\%) & $1.06^{c}$ & $1.06^{c}$ & $1.10^{b}$ & $1.11^{\mathrm{a}}$ & $1.12^{\mathrm{a}}$ & 0.004 & $<0.001$ \\
\hline AlA in feed (\%) & 0.26 & 0.26 & 0.26 & 0.26 & 0.26 & - & - \\
\hline GE in feed (MJ/kg) & 16.90 & 16.90 & 16.90 & 16.90 & 16.90 & - & - \\
\hline AM (\%) & $79.44^{d}$ & $79.82^{c}$ & $80.33^{b}$ & $81.11^{\mathrm{a}}$ & $81.39^{\mathrm{a}}$ & 0.27 & $<0.001$ \\
\hline AME $(\mathrm{MJ} / \mathrm{kg})$ & $13.43^{d}$ & $13.51^{c}$ & $13.60^{b}$ & $13.72^{\mathrm{a}}$ & $13.77^{\mathrm{a}}$ & 0.05 & $<0.001$ \\
\hline MEI $\left(\mathrm{kJ} / \mathrm{kg}\right.$ of $\left.B W^{0.75} / \mathrm{d}\right)$ & $1,934.25^{\mathrm{a}}$ & $1,805.63^{b}$ & $1,720.48^{c}$ & $1,625.33^{d}$ & $1,498.00^{\mathrm{e}}$ & 9.20 & $<0.001$ \\
\hline $\operatorname{RE}\left(\mathrm{kJ} / \mathrm{kg}\right.$ of $\left.\mathrm{BW}^{0.75} / \mathrm{d}\right)$ & $984.99^{\mathrm{a}}$ & $892.64^{b}$ & $822.22^{c}$ & $741.27^{d}$ & $622.82^{\mathrm{e}}$ & 5.61 & $<0.001$ \\
\hline $\mathrm{HP}\left(\mathrm{kJ} / \mathrm{kg}\right.$ of $\left.\mathrm{BW}^{0.75} / \mathrm{d}\right)$ & $949.26^{a}$ & $913.00^{b}$ & $898.26^{c}$ & $884.06^{d}$ & $835.19^{\mathrm{e}}$ & 9.50 & $<0.001$ \\
\hline
\end{tabular}

SEM, standard error of the mean; GE, gross energy; AIA, acid-insoluble ash; AM, apparent metabolizable rate of energy; AME, apparent metabolizable energy; MEI, metabolizable energy intake; RE, retained energy; $H P$, heat production.

${ }^{\text {a-e }}$ Means within a row lacking a common superscript differ $(p<0.05)$.

Table 5. Regression equations of RE and $\log _{10} \mathrm{HP}$ as a function of MEl

\begin{tabular}{|c|c|c|c|c|c|c|c|}
\hline \multirow{2}{*}{ Regression equations } & \multirow{2}{*}{$\mathrm{R}^{2}$} & \multirow{2}{*}{ RMSE } & \multirow{2}{*}{$p$-value } & \multicolumn{2}{|c|}{ Requirements $\left(\mathrm{kJ} / \mathrm{kg}\right.$ of $\left.\mathrm{BW}^{0.75} / \mathrm{d}\right)$} & \multicolumn{2}{|c|}{ Efficiencies } \\
\hline & & & & $\mathrm{NE}_{\mathrm{m}}$ & $\mathrm{ME}_{\mathrm{m}}$ & $\mathrm{K}_{\mathrm{m}}$ & $\mathrm{K}_{\mathrm{g}}$ \\
\hline $\log _{10} \mathrm{HP}=2.74+0.00012 \times \mathrm{MEI}$ & 0.939 & 0.005 & $<0.001$ & 549.54 & - & 0.88 & - \\
\hline $\mathrm{RE}=0.75 \mathrm{MEI}-469.19$ & 0.993 & 9.605 & $<0.001$ & - & 625.59 & - & 0.75 \\
\hline
\end{tabular}

$\mathrm{RE}$, retained energy; $\mathrm{HP}$, heat production; $\mathrm{MEI}$, metabolizable energy intake; RMSE, root mean square error; BW, body weight; $\mathrm{NE}_{\mathrm{m},}$, net energy requirements of maintenance; $\mathrm{ME}_{\mathrm{m},}$ metabolizable energy requirements for maintenance; $\mathrm{K}_{m}$, ME utilization for maintenance; $\mathrm{K}_{\mathrm{g}}$ ME utilization for deposition energy.

Table 6. Body composition of ducks at different ages

\begin{tabular}{|c|c|c|c|c|c|}
\hline \multirow{2}{*}{ Items } & \multicolumn{3}{|c|}{ Age } & \multirow{2}{*}{ SEM } & \multirow{2}{*}{$p$-value } \\
\hline & $7 d$ & $14 \mathrm{~d}$ & $21 \mathrm{~d}$ & & \\
\hline Water (\%) & $72.55^{\mathrm{a}}$ & $68.01^{b}$ & $63.97^{c}$ & 0.23 & $<0.001$ \\
\hline Energy $(\mathrm{kJ} / \mathrm{g})$ & $6.99^{c}$ & $8.41^{b}$ & $9.83^{\mathrm{a}}$ & 0.08 & $<0.001$ \\
\hline Protein (\%) & $14.02^{c}$ & $14.64^{b}$ & $16.50^{\mathrm{a}}$ & 0.20 & $<0.001$ \\
\hline Fat $(\%)$ & $16.85^{\mathrm{a}}$ & $15.64^{b}$ & $13.68^{c}$ & 0.31 & $<0.001$ \\
\hline BW (g) & $171.12^{c}$ & $572.70^{b}$ & $1,143.88^{a}$ & 6.35 & $<0.001$ \\
\hline$B E(k J)$ & $1,196.28^{c}$ & $4,815.71^{b}$ & $11,264.76^{\mathrm{a}}$ & 55.60 & $<0.001$ \\
\hline BWE (kJ/g) & 6.99 & 8.41 & 9.85 & 9.10 & $<0.001$ \\
\hline
\end{tabular}

SEM, standard error of the mean; BW, mean body weight of the ducks; BE, carcasses energy content; BWE, energy content of body weight.

${ }^{a-c}$ Means within a row lacking a common superscript differ $(p<0.05)$.

$\mathrm{NE}_{\mathrm{g}}$ and $\mathrm{K}_{\mathrm{g}}$, the value of $\mathrm{ME}_{\mathrm{g}}$ for ducks was calculated as 13.88

$\mathrm{kJ} / \mathrm{g}$.

According to the body fat and protein deposition of ducks and the energy requirement of fat and protein deposition, the values of $R E$ as fat $\left(R E_{f}\right)$ and $R E$ as protein $\left(R E_{p}\right)$ at different level of intake are shown in Table 7. The values of $\mathrm{RE}_{\mathrm{f}}$ and $\mathrm{RE}_{\mathrm{p}}$ of the ad libitum group were 621.85 and $381.98 \mathrm{~kJ} / \mathrm{kg}$ of $\mathrm{BW}^{0.75} / \mathrm{d}$, respectively. With the decrease in level of intake, the values of $\mathrm{RE}_{\mathrm{f}}$ and $\mathrm{RE}_{\mathrm{p}}$ decreased significantly. The values of $\mathrm{K}_{\mathrm{f}}$ and $\mathrm{K}_{\mathrm{p}}$ were determined by a multiple linear regression equation of the MEI as a function of $\mathrm{RE}_{\mathrm{f}}$ and $\mathrm{RE}_{\mathrm{p}}$, and the values of $\mathrm{K}_{\mathrm{f}}$ and $\mathrm{K}_{\mathrm{p}}$ were 0.96 and 0.60 , respectively, which were obtained from the following regression equation:

$$
\begin{aligned}
M E I & =149.56+1.67 \times \mathrm{RE}_{\mathrm{p}}+1.08 \times \mathrm{RE}_{\mathrm{f}}\left(\mathrm{n}=15, \mathrm{R}^{2}=0.991,\right. \\
\mathrm{RMSE} & =3.623, \mathrm{p}<0.0001) .
\end{aligned}
$$

\section{DISCUSSION}

According to Latshaw and Moritz [23], broiler chickens with

\begin{tabular}{|c|c|c|c|c|c|c|c|}
\hline \multirow{2}{*}{ Item $^{1)}$} & \multicolumn{5}{|c|}{ Feeding level } & \multirow{2}{*}{ SEM } & \multirow{2}{*}{$p$-value } \\
\hline & Ad libitum & $85 \%$ ad libitum & $75 \%$ ad libitum & $65 \%$ ad libitum & $55 \%$ ad libitum & & \\
\hline$R E_{f}\left(k J / k g\right.$ of $\left.B W^{0.75} / d\right)$ & $621.85^{\mathrm{a}}$ & $544.29^{b}$ & $468.94^{c}$ & $402.09^{d}$ & $337.92^{e}$ & 6.19 & $<0.001$ \\
\hline $\mathrm{RE}_{\mathrm{p}}\left(\mathrm{kJ} / \mathrm{kg}\right.$ of $\left.B W^{0.75} / \mathrm{d}\right)$ & $381.98^{\mathrm{a}}$ & $359.81^{b}$ & $346.72^{c}$ & $332.19^{d}$ & $310.43^{e}$ & 4.94 & $<0.001$ \\
\hline
\end{tabular}

Table 7. The values of $R E_{f}$ and $R E_{p}$ of 2 to 3-week-old ducks

SEM, standard error of the mean; BW, body weight.

1) $R E_{f}$ retained energy as fat, calculation based on energy value of fat $(39.22 \mathrm{~kJ} / \mathrm{g}) ; R E_{p r}$ retained energy as protein, calculation based on energy value of protein (23.69 $\left.\mathrm{kJ} / \mathrm{g}\right)$.

${ }^{a-e}$ Means within a row lacking a common superscript differ $(p<0.05)$. 
limited levels of feed gained less ADG and the FCR increased. Consistent with these results, we obtained reduced values of ADFI and ADG and an increase in FCR value when ducks were fed at severely limited levels. Latshaw and Bishop [24] predicted greater maintenance requirements when broiler chickens did not take enough energy daily, because the energy that was consumed had dramatic effects on the proportion of energy from feed that was used for maintenance and production. Its means the energy obtained from feed were mostly used to maintain normal physiological functions, the less energy were retention in body [25], thus, the BW increased less than normal feed intake ducks, when ducks were feed restriction.

As noted by Saleh et al [26], an increase in the availability of nutrients in diets results in changes in lipogenesis that cause changes in the composition of the carcasses. Morris [27] also found that the MEI affects the body composition of broiler chickens because animals have a tendency deposit protein rather than fat when they eat less feed. According to report of Boekholt et al [22], broiler chickens only retained protein as energy intake was restricted, but the most energy is deposited as fat when animal intake higher level energy. This might explain the increase in body protein content and reduction of carcasses moisture with the decrease in levels of feed, although the protein tissue contains more moisture than fat tissue. The value of $\mathrm{BE}$ decreased with the decrease in levels of feed and was related to the reduction of body fat content of ducks. Concerning gain with age, the BW, protein and energy contents increased, the carcasses moisture and fat content decreased. Results of experiment on broilers chickens, broiler pullets and quail also show that protein content increases and carcasses moisture decreases with age [28-30]. In ducks, the body fat content decreased with age, with the results in contrast to earlier studies of broiler chickens [31] and pullets [32] and quail $[28,33]$, a discrepancy that might be due to the different ages and species, the ducks were reared for only two weeks in this experiment.

Sakomura et al [34] obtained AMEn values for broiler chickens fed $75 \%$ and $50 \%$ of ad libitum intake that were greater than these with ad libitum intake. Zancanela et al [33] found a similar performance in meat quail, which had the greatest $\mathrm{AME}_{\mathrm{n}}$ value when fed $30 \%$ of ad libitum intake. For 21 to 42-day-old broiler chickens, the highest AME were shown at $40 \%$ of ad libitum intake group [25]. Consistent with these results, in the present study, the AME value of diet increased with the decrease in the level of intake, which might be due to the increase of feed digestion volume in the digestive tract caused by the decrease in the level of intake. By contrast, as the level of intake decreased in a study of growing and finishing pigs, the ME of the diet was less for pigs, and the excretion of energy in urine increased [15]. Such differences may be due to the diversity of the diges- tive tracts between pig and poultry, with the reduction in feed intake resulting in longer transit times through the gastrointestinal tract in pigs, therefore, an increase in the energy lost as methane.

In studies of poultry, $\mathrm{NE}_{\mathrm{m}}$ values for broilers and quails have been reported. In this study, the NE requirement for maintenance was determined by a linear regression equation of FHP as a function of the ME intake of duck. Sakomura et al [31] obtained $\mathrm{NE}_{\mathrm{m}}$ values of 376.52 to $499.15 \mathrm{~kJ} / \mathrm{kg}$ of $\mathrm{BW}^{0.75} / \mathrm{d}$ for broiler chickens reared at different room temperature. As well, Liu et al [35] determined the $\mathrm{NE}_{\mathrm{m}}$ for broiler chickens to be between 386 and $462 \mathrm{~kJ} / \mathrm{kg}$ of BW $\mathrm{BW}^{0.75} / \mathrm{d}$ according to different methods and regression equations. Jordão Filho et al [28] determined the $\mathrm{NE}_{\mathrm{m}}$ of Japanese and European quail at $18^{\circ} \mathrm{C}$, $24^{\circ} \mathrm{C}$, and $28^{\circ} \mathrm{C}$ and found values of $218.36,207.07$, and 203.43 and $240.87,242.84$, and $230.91 \mathrm{~kJ} / \mathrm{kg}$ of $\mathrm{BW}^{0.75} / \mathrm{d}$, respectively. In the present study, the $\mathrm{NE}_{\mathrm{m}}$ values of ducks were greater than these studies about broiler chickens and quails. This may be due to the greater weight of ducks, because the $\mathrm{NE}_{\mathrm{m}}$ was linearly related to metabolic BW [36]. Therefore, the temperature and the species affect the energy requirements for maintenance in birds. Besides, the rearing environment also affects the $\mathrm{NE}_{\mathrm{m}}$ of birds, Jordão Filho et al [28] found that quail reared on the floor required more energy for maintenance than these reared in cages because the larger floor space allowed more locomotor activity of birds. In broiler chickens, short-term fasting significantly decrease the rectal temperature of broiler chickens [37]. With the feeding level increase, the HP increased linearly, then the heat as sensible heat loss rather than evaporative heat loss, this may be change the optimal temperature [38]. The change of optimal temperature caused by different feeding level may be led to locomotor activity. As report of Nourmohammadi et al [25], broiler chickens have reduced $\mathrm{NE}_{\mathrm{m}}$ when were supplied with the pallet food and xylanase, but arabinoxylans has no effect on that [39]. Thus, there is complicated reason that influence the $\mathrm{NE}_{\mathrm{m}}$ of birds.

The $\mathrm{ME}_{\mathrm{m}}$ value of ducks obtained in this study was 625.59 $\mathrm{kJ} / \mathrm{kg}$ of $\mathrm{BW}^{0.75} / \mathrm{d}$, which is in the range of values obtained by Sakomura et al [31], who determined the $\mathrm{ME}_{\mathrm{m}}$ of broiler chickens at different feeding temperature and found values of 469.03 to $660.24 \mathrm{~kJ} / \mathrm{kg}$ of BW $\mathrm{BW}^{0.75} / \mathrm{d}$. Our result was also similar to the report from Liu et al [35], which showed the $\mathrm{ME}_{\mathrm{m}}$ of broiler breeding cocks were 594 and $618 \mathrm{~kJ} / \mathrm{kg}$ of $\mathrm{BW}^{0.75} / \mathrm{d}$ by indirect calorimetry. In a study on quail, Jordão Filho et al [28] reported $\mathrm{ME}_{\mathrm{m}}$ values of 443.92 and 448.11 $\mathrm{kJ} / \mathrm{kg}$ of $\mathrm{BW}^{0.75} / \mathrm{d}$ in quail reared in cages and on the floor, respectively. However, Zancanela et al [33] found an $\mathrm{ME}_{\mathrm{m}}$ value of $659 \mathrm{~kJ} / \mathrm{kg}$ of BW $\mathrm{BW}^{0.75} / \mathrm{d}$, with the discrepancy possibly due to a high breeding density. These data confirmed that birds increase HP to maintain metabolic stability when reared at temperatures above or below their thermoneutral zone. Differences among species may explain the variations in re- 
quirements for maintenance, ducks have greater BW than broilers at same age, because the ducks has higher BW than broilers.

The energy absorbed from feed is used to satisfy the requirements of maintenance for animals, and the surplus energy is deposited in body tissues as protein or lipids, which account for two-thirds of the energy requirement (NRC, 2012). Silva et al $[40,41]$ obtained $\mathrm{NE}_{\mathrm{g}}$ values for 1 to 12 and 15 to 32-dayold laying quail of 5.44 and $8.58 \mathrm{~kJ} / \mathrm{g}$, respectively. Similarly, values of $\mathrm{NE}_{\mathrm{g}}$ for 0 to 14 and 14 to 35-day-old meat quail were 5.72 and $8.90 \mathrm{~kJ} / \mathrm{g}$, respectively [33]. For 3 to 8,9 to 14 , and 15 to 20 -week-old broiler breeder pullets, $\mathrm{NE}_{\mathrm{g}}$ values were $8.16,7.24$, and $9.37 \mathrm{~kJ} / \mathrm{g}$, respectively [42]. In the present study, the $\mathrm{NE}_{\mathrm{g}}$ value for ducks was $10.41 \mathrm{~kJ} / \mathrm{g}$, which is higher than that for quail and broiler breeder pullets. This may be due to the ducks has higher growth rate than others. The increase in $\mathrm{NE}_{\mathrm{g}}$ with age may be related to lower utilization when birds are close to sexual maturity. Differences in gender also affect the $\mathrm{NE}_{\mathrm{g}}$ of birds [40]. In addition, ducks deposited more subcutaneous fat than chickens, as we know, and the energy requirement of fat more than that of protein [43].

In the present study, the value of $\mathrm{ME}_{\mathrm{g}}$ for ducks was 13.88 $\mathrm{kJ} / \mathrm{g}$, which is higher than these for broiler breeder pullets obtained by Sakomura et al [42], who determined $\mathrm{ME}_{\mathrm{g}}$ values of 3 to 8,9 to 14 , and 15 to 20 -week-old broiler breeder pullets of $11.80,10.46$, and $13.56 \mathrm{~kJ} / \mathrm{g}$, respectively. Comparatively, the report of Longo et al [44] showed the $\mathrm{ME}_{\mathrm{g}}$ values for 0 to 3,4 to 6 , and 7 to 8 -week-old broiler chickens were 15.56 , 16.65 , and $17.61 \mathrm{~kJ} / \mathrm{g}$ for males and $16.69,16.44$, and 29.46 $\mathrm{kJ} / \mathrm{g}$ for females, respectively, which were higher than the value of ducks. The differences in species was one reason for these differences, and as noted by Zancanela et al [33], the $\mathrm{ME}_{\mathrm{g}}$ is variable based on gender, lineage and species. As show as Sakomura et al [42], the $\mathrm{ME}_{\mathrm{g}}$ is also related to variability in body composition, growth rate, and protein and fat deposition rates, which are affected by genetics, age, and the environment in which birds were reared.

In this study, the value of $\mathrm{K}_{\mathrm{f}}$ was greater than $\mathrm{K}_{\mathrm{p}}$, which was consistent with the results obtained by Zancanela et al [33], who obtained $K_{f}$ and $K_{p}$ values for meat quail of 0.79 and 0.32, respectively. Sakomura et al [31] found that $\mathrm{K}_{\mathrm{p}}(0.58)$ was greater than $K_{f}(0.55)$ when broiler chickens were reared at optimum ambient temperature. By contrast, values of $\mathrm{K}_{\mathrm{f}}$ and $\mathrm{K}_{\mathrm{p}}$ for broiler breeder pullets were 1.04 and 0.46 , respectively [42]. Nieto et al [45] determined the value of $K_{f}$ for male broilers to be between 0.65 and 1.27 and that for $\mathrm{K}_{\mathrm{p}}$ to be between 0.40 and 0.58. MacLeod [46] reported that the values of $\mathrm{K}_{\mathrm{f}}$ and $\mathrm{K}_{\mathrm{p}}$ for female broilers were between 1.02 and 1.03 and 0.47 and 0.57 , respectively. In this study, the value of $\mathrm{K}_{\mathrm{f}}$ for ducks was similar to these for broilers and broiler breeder pullets, but the value of $\mathrm{K}_{\mathrm{p}}$ for ducks was greater than these values. According to Sakomura et al [31], the tempera- ture, gender, age, diet, and methods used for detection affect the values of $K_{f}$ and $K_{p}$. Furthermore, the $K_{p}$ represents the ability of the animal for protein synthesis and deposition, which is relatively more species specific.

The $\mathrm{K}_{\mathrm{m}}$ and $\mathrm{K}_{\mathrm{g}}$ represent the efficiency of $\mathrm{NE}_{\mathrm{m}}$ and $\mathrm{NE}_{\mathrm{g}}$ conversion from $\mathrm{ME}_{\mathrm{m}}$ and $\mathrm{ME}_{\mathrm{g}}$, respectively, in this study, the values of $\mathrm{K}_{\mathrm{m}}$ and $\mathrm{K}_{\mathrm{g}}$ for ducks were 0.88 and 0.75 , respectively. The value of $\mathrm{K}_{\mathrm{g}}$ in the present study is similar to that of male growing turkeys (0.76) but higher than that of broiler chickens ( 0.63 to 0.69 ) and broiler breeder pullets ( 0.57 to 0.64 ) $[31,42,47]$. Working with broiler breeder pullets, Sakomura et al [42] obtained $\mathrm{K}_{\mathrm{m}}$ values of 0.72 to 0.76 at different temperatures, and for broiler chickens at different temperatures, the values were 0.76 to 0.80 [31]. The greater $K_{m}$ value obtained in the present study was expected because the ducks were less active than broiler chickens, which caused less of the MEI to be expended on daily activities. According to Jordão Filho et al [28], the $\mathrm{K}_{\mathrm{m}}$ value of quail reared in cages was greater than that of quail reared on floor pens, which can be explained by the increased energy expenditure of locomotor activities on floor pens. Additionally, the dissimilarity of feed composition and fat deposition rate for growing animals contributes to such differences $[45,48]$. Those data further confirm that ducks are more capable of energy deposition than broilers.

In conclusion, we used the linear regression method to estimate $\mathrm{NE}_{\mathrm{m}}$ and $\mathrm{ME}_{\mathrm{m}}$ values of 549.54 and $625.59 \mathrm{~kJ} / \mathrm{kg}$ of $\mathrm{BW}^{0.75} / \mathrm{d}$, for 2 to 3-week-old Cherry Valley ducks, respectively. The requirements of $\mathrm{NE}$ and $\mathrm{ME}$ for energy deposition were 10.41 and $13.88 \mathrm{~kJ} / \mathrm{g}$, respectively, the values obtained via the comparative slaughter method. Thus, the equation to predict the NE requirements for 2 to 3-week-old Cherry Valley ducks was the following: $\mathrm{NE}=549.54 \mathrm{BW}^{0.75}+10.41 \Delta \mathrm{W}$, where $\Delta \mathrm{W}$ is the weight gain $(\mathrm{g})$.

\section{CONFLICT OF INTEREST}

We certify that there is no conflict of interest with any financial organization regarding the material discussed in the manuscript.

\section{ACKNOWLEDGMENTS}

This work was supported by the Academy of Kechuang Feed Industry in Sichuan under Grant (2013NZ0054).

\section{REFERENCES}

1. De Groote G. A comparison of a new net energy system with the metabolisable energy system in broiler diet formulation, performance and profitability. Br Poult Sci 1974;15:75-95. https://doi.org/10.1080/00071667408416082 
2. van Milgen J, Noblet J, Dubois S. Energetic efficiency of starch, protein and lipid utilization in growing pigs. J Nutr 2001;131: 1309-18. https://doi.org/10.1093/jn/131.4.1309

3. Swick RA, Wu SB, Zuo JJ, Rodgers N, Barekatain MR, Choct M. Implications and development of a net energy system for broilers. Anim Prod Sci 2013;53:1231-7. https://doi.org/10. 1071/AN13204

4. Sakomura NK, Resende KT, Fernandes JBK, Rabelo CBV, Longo FA, Neme R. Net energy requirement models for broiler breeders, laying hens and broilers. Proceedings of the 15th European Symposium on Poultry Nutrition; 2005 25-29 September 2005; Balatonfüred, Hungary.

5. Klis JDVD, Kwakernaak C, Jansman A, Blok M. Energy in poultry diets: adjusted AME or net energy. Proceedings of the 21st Annual Australian Poultry Science Sumposium; 2010 1-3rd February 2010; Sydney, New South Wales, Australia.

6. Kerr BJ, Southern LL, Bidner TD, Friesen KG, Easter RA. Influence of dietary protein level, amino acid supplementation, and dietary energy levels on growing-finishing pig performance and carcass composition. J Anim Sci 2003;81: 3075-87. https://doi.org/10.2527/2003.81123075x

7. Acosta JA, Boyd RD, Patience JF. Digestion and nitrogen balance using swine diets containing increasing proportions of coproduct ingredients and formulated using the net energy system. J Anim Sci 2017;95:1243-52. https://doi.org/10.2527/jas.2016. 1161

8. Woyengo TA, Jha R, Beltranena E, Pharazyn A, Zijlstra RT. Nutrient digestibility of lentil and regular-and low-oligosaccharide, micronized full-fat soybean fed to grower pigs. J Anim Sci 2014;92:229-37. https://doi.org/10.2527/jas.20136555

9. de Lange CFM, Birkett H. Characterization of useful energy content in swine and poultry feed ingredients. Can J Anim Sci 2005;85:269-80. https://doi.org/10.4141/A04-057

10.de Lange K, van Milgen J, Noblet J, Dubois S, Birkett S. Previous feeding level influences plateau heat production following a $24 \mathrm{~h}$ fast in growing pigs. Br J Nutr 2006;95:1082-7. https:// doi.org/10.1079/BJN20061748

11.Zhou W, Yamamoto S. Effects of environmental temperature and heat production due to food intake on abdominal temperature, shank skin temperature and respiration rate of broilers. Br Poult Sci 1997;38:107-14. https://doi.org/10.1080/000716 69708417949

12. Koh K, Macleod M. Circadian variation in heat production and respiratory quotient in growing broilers maintained at different food intakes and ambient temperatures. Br Poult Sci 1999;40:353-6. https://doi.org/10.1080/00071669987449

13. Birkett S, de Lange K. A computational framework for a nutrient flow representation of energy utilization by growing monogastric animals. Br J Nutr 2001;86:661-74. https://doi. org/10.1079/BJN2001442

14.Ning D, Yuan JM, Wang YW, Peng YZ, Guo YM. The net energy values of corn, dried distillers grains with solubles and wheat bran for laying hens using indirect calorimetry method. Asian-Australas J Anim Sci 2014;27:209-16. https://doi.org/ 10.5713/ajas.2013.13243

15.Zhang GF, Liu DW, Wang FL, Li DF. Estimation of the net energy requirements for maintenance in growing and finishing pigs. J Anim Sci 2014;92:2987-95. https://doi.org/10.2527/jas. 2013-7002

16. Milgen J, Noblet J. Partitioning of energy intake to heat, protein, and fat in growing pigs. J Anim Sci 2003;81(Suppl 2):E86-93. https://doi.org/10.2527/2003.8114_suppl_2E86x

17. Noblet J, Milgen JV, Dubois S. Utilisation of metabolisable energy of feeds in pigs and poultry: interest of net energy systems? Proceedings of the 21st Annual Australian Poultry Science Sumposium; 2010 1-3rd February 2010; Sydney, New South Wales, Australia.

18.Lofgreen GP, Garrett WN. A system for expressing net energy requirements and feed values for growing and finishing beef cattle. J Anim Sci 1968;27:793-806. https://doi.org/10.2527/ jas1968.273793x

19. Latimer G. Official methods of analysis of AOAC International. 19th ed. Gaithersburg, MD, USA: AOAC International; 2012.

20. Fosoul SSAS, Azarfar A, Gheisari A, Khosravinia H. Energy utilisation of broiler chickens in response to guanidinoacetic acid supplementation in diets with various energy contents. Br J Nutr 2018;120:131-40. https://doi.org/10.1017/S000711 4517003701

21. Farrell D. General principles and assumptions of calorimetry. In: Morris TR, Freeman BM, editors. Energy requirements of poultry. Edinberg, UK: British Poultry Science Ltd.; 1974. pp. 1-24.

22. Boekholt HA, van der Grinten P, Schreurs VV, Los MJ, Leffering CP. Effect of dietary energy restriction on retention of protein, fat and energy in broiler chickens. Br Poult Sci 1994;35:60314. https://doi.org/10.1080/00071669408417725

23. Latshaw JD, Moritz JS. The partitioning of metabolizable energy by broiler chickens. Poult Sci 2009;88:98-105. https://doi.org/ 10.3382/ps.2008-00161

24. Latshaw J, Bishop B. Energy required for maintenance of broiler chickens and the change due to body fat content. J Anim Vet Adv 2004;3:19-23.

25. Nourmohammadi R, Khosravinia H, Afzali N. Effects of feed form and xylanase supplementation on metabolizable energy partitioning in broiler chicken fed wheat-based diets. J Anim Physiol Anim Nutr 2018;102:1593-600. https://doi.org/10. 1111/jpn.12980

26. Saleh EA, Watkins SE, Waldroup AL, Waldroup PW. Effects of dietary nutrient density on performance and carcass quality of male broilers grown for further processing. Int J Poult Sci 2004;3:1-10. https://doi.org/10.3923/ijps.2004.1.10

27.Morris TR. Nutrition of chicks and layers. Worlds Poult Sci J 2004;60:5-18. https://doi.org/10.1079/WPS20031 
28. Jordão Filho J, Silva JHVd, Silva CT, Costa FGP, Sousa JMBd, Givisiez PEN. Energy requirement for maintenance and gain for two genotypes of quails housed in different breeding rearing systems. Rev Bras Zootec 2011;40:2415-22. https://doi.org/ 10.1590/S1516-35982011001100019

29. Martin PA, Bradford GD, Gous RM. A formal method of determining the dietary amino acid requirements of layingtype pullets during their growing period. Br Poult Sci 1994; 35:709-24. https://doi.org/10.1080/00071669408417737

30. Bartov I, Plavnik I. Moderate excess of dietary protein increases breast meat yield of broiler chicks. Poult Sci 1998;77:680-8. https://doi.org/10.1093/ps/77.5.680

31. Sakomura NK, Longo FA, Oviedo-Rondon EO, Boa-Viagem C, Ferraudo A. Modeling energy utilization and growth parameter description for broiler chickens. Poult Sci 2005;84:13639. https://doi.org/10.1093/ps/84.9.1363

32. Neme R, Sakomura NK, Fukayama EH, et al. Growth curves and deposition of body components in pullets of different strains. Rev Bras Zootec 2006;35:1091-100. https:/doi.org/ 10.1590/S1516-35982006000400021

33.Zancanela V, Marcato SM, Furlan AC, et al. Models for predicting energy requirements in meat quail. Livest Sci 2015;171: 12-9. https://doi.org/10.1016/j.livsci.2014.10.002

34. Sakomura NK, Longo FA, Rabello CB-V, Watanabe K, Pelícia K, Freitas ER. Effect of dietary metabolizable energy on energy metabolism and performance in broiler chickens. Rev Bras Zootec 2004;33:1758-67. https://doi.org/10.1590/S1516-3598 2004000700014

35. Liu W, Lin $\mathrm{CH}$, Wu ZK, et al. Estimation of the net energy requirement for maintenance in broilers. Asian-Australas J Anim Sci 2017;30:849-56. https://doi.org/10.5713/ajas.16. 0484

36. Noblet J, Dubois S, Lasnier J, et al. Fasting heat production and metabolic BW in group-housed broilers. Animal 2015;9: 1138-44. https://doi.org/10.1017/S1751731115000403

37. Özkan S, Akbaş Y, Altan Ö, Altan A, Ayhan V, Özkan K. The effect of short-term fasting on performance traits and rectal temperature of broilers during the summer season. Br Poult Sci 2003;44:88-95. https://doi.org/10.1080/00071660310000 85292

38. Wiernusz CJ, Teeter RG. Feeding effects on broiler thermobalance during thermoneutral and high ambient temperature exposure. Poult Sci 1993;72:1917-24. https://doi.org/10.3382/ ps.0721917

39. Morgan NK, Keerqin C, Wallace A, Wu SB, Choct M. Effect of arabinoxylo-oligosaccharides and arabinoxylans on net energy and nutrient utilization in broilers. Anim Nutr 2019; 5:56-62. https://doi.org/10.1016/j.aninu.2018.05.001

40.Silva JHVD, Silva MBD, Jordão Filho J, et al. Maintenance and weight gain of crude protein and metabolizable energy requirements of japanese quails (Coturnix coturnix japonica) from 1 to 12 days of age. Rev Bras Zootec 2004;33:1209-19. https://doi.org/10.1590/S1516-35982004000500013

41.Silva JHVD, Silva MBD, Jordão Filho J, et al. Maintenance and weight gain in crude protein and metabolizable energy requirements of japanese quails (Coturnix coturnix japonica) from 15 to 32 days of age. Rev Bras Zootec 2004;33:1220-30. https:// doi.org/10.1590/S1516-35982004000500014

42.Sakomura NK, Silva R, Couto HP, Coon C, Pacheco CR. Modeling metabolizable energy utilization in broiler breeder pullets. Poult Sci 2003;82:419-27. https://doi.org/10.1093/ps/ 82.3.419

43. Murawska D. The effect of age on the growth rate of tissues and organs and the percentage content of edible and nonedible carcass components in Pekin ducks. Poult Sci 2012;91:20308. https://doi.org/10.3382/ps.2011-02083

44.Longo FA, Sakomura NK, Rabello CB-V, Figueiredo AN, Fernandes JBK. Metabolizable energy requirements for maintenance and growth of broilers. Rev Bras Zootec 2006;35: 119-25. https://doi.org/10.1590/S1516-35982006000100015

45. Nieto R, Prieto C, Fernandez-Figares I, Aguilera JF. Effect of dietary protein quality on energy metabolism in growing chickens. Br J Nutr 1995;74:163-72. https://doi.org/10.1079/ BJN19950120

46. MacLeod MG. Energy and nitrogen intake, expenditure and retention at 20 degrees in growing fowl given diets with a wide range of energy and protein contents. Br J Nutr 1990;64:62537. https://doi.org/10.1079/BJN19900066

47. Rivera-Torres V, Noblet J, Dubois S, van Milgen J. Energy partitioning in male growing turkeys. Poult Sci 2010;89:530-8. https://doi.org/10.3382/ps.2009-00353

48. Carré B, Lessire M, Juin H. Prediction of the net energy value of broiler diets. Animal 2014;8:1395-401. https://doi.org/10. $1017 /$ S175173111400130X 